\title{
Acquisition of posture control through of high postures in extremely preterm infants with diagnoses of Bronchopulmonary Dysplasia severe: case report
}

\section{Aquisição do controle postural por meio de posturas altas em prematuro extremo com diagnóstico de displasia broncopulmonar grave: relato de caso}

Tamiris Beppler Martins'1, Camila Fadel da Silva', Aline Dandara Rafael1', Micheli Martinello', Cíntia Jonhston², Gilmar Moraes Santos ${ }^{1}$

\begin{abstract}
Introduction: With the increased survival of immature newborns, the incidence of bronchopulmonary dysplasia is increasing, as well as a significant increase in the number of children with delayed neuropsychomotor development. Objective: To report the experiences in a physical therapy intervention program based on the neuroevolutives high positions in the development of cervical control and trunk, in a higk-risk young child diagnosed with bronchopulmonary dysplasia. Method: Case report of a female child, chronological age of six months, corrected age of two and a half months, extremely premature very low birth weight, which held 28 sessions of physiotherapy. Results: After treatment, there was an increase of active movement; in the prone position was reached full cervical extension; the roll from supine to prone; in the sitting position remained good postural control; she remained in a standing position with cervical support and trunk requiring support at lower distal members. Conclusion: The high positions allowed greater interaction between child and the environment around herself, thus enabling a breakthrough in motor development for the acquisition of control cervical and trunk.

Keywords: Physical therapy specialty; Broncopulmonary dysplasia; Child development.

\section{RESUMO}

Introdução: Com o aumento da sobrevida de recém-nascidos imaturos, a incidência de displasia broncopulmonar vem aumento, bem como um significativo acréscimo do número de crianças com atraso no desenvolvimento neuropsicomotor. Objetivo: Relatar as experiências vivenciadas em um programa de fisioterapia baseado em posturas neuroevolutivas altas no desenvolvimento do controle cervical e de tronco, em uma criança de risco com diagnóstico de displasia broncopulmonar. Método: Relato de caso de uma criança do sexo feminino, idade cronológica de seis meses, idade corrigida de dois meses e meio, prematura extrema de muito baixo peso, a qual realizou 28 sessões de fisioterapia. Resultado: Após tratamento, foi observado aumento da movimentação ativa; na posição prona atingiu-se a extensão cervical completa; o rolar de supino para prono; na posição sentada manteve bom controle postural; permaneceu na posição em pé com sustentação cervical e de tronco necessitando de apoio em membros inferiores distalmente. Conclusão: As posturas altas permitiram uma maior interação da criança com o ambiente ao seu redor, possibilitando assim, um avanço no desenvolvimento motor pela aquisição do controle cervical e de tronco.
\end{abstract}

Palavras-chave: Fisioterapia; Displasia broncopulmonar; Desenvolvimento infantil.

Corresponding author: Tamiris Beppler Martins. Rua Vidal Gregório Pereira, 363, Zip Code: 88095-030, Florianópolis (SC), Brazil.

E-mail: tamirismartins@outlook.com

${ }^{1}$ Universidade Estadual de Santa Catarina (UDESC), Florianópolis (SC), Brazil.

Full list of author information is available at the end of the article.

Financial support: None.

Submission date 05 December 2015; Acceptance date 29 February 2016; Publication date 08 March 2016 


\section{INTRODUCTION}

Infants at risk for developmental delay are those susceptible to neuropsychomotor developmental delay (NPMD), which may occur due to pre-, peri- and / or post-natal. ${ }^{(1,2)}$

Due to the increased survival of immature infants, the incidence of bronchopulmonary dysplasia (BPD) (23-83\%) has been increasing ${ }^{(3,4)}$, as well as addition of children with neurocognitive abnormalities ${ }^{(5)}$ and with neuropsychomotor development delay. ${ }^{(6)}$

Smaller delays rates in psychomotor development is due to the scientific advances, the improvement of hospital facilities and the increase in the number of techniques used. ${ }^{(5)}$ Once prolonged hospitalization in an unstimulated environment ${ }^{(7)}$, as well as gestational age and birth weight ${ }^{(8)}$, are factors that increase the biological and environmental risks, thus causing deficits in postnatal development. ${ }^{(9)}$

The evolution of these infants can be used for early diagnosis and intervention, because the sooner started stimulation, the greater will be the use of brain plasticity, with minor development changes and less impact on the future life of the child ${ }^{(10-13)}$. Vestibular stimulation, i.e., the exchange of positions against the action of gravity favors the gain of the posture control, thus improving the overall engine development ${ }^{(14)}$.

However, until the present date, no studies were found that evaluated the effect of anti-gravity positions in extremely premature infant with neuropsychomotor development delay. It is believed that high neuroevolutivas postures lead to further environmental stimulation and brain plasticity, thus improving the psychomotor development.

Thus, the present study aims to report the experiences in a physical therapy program based on high neuro-evolutionary positions on the development of cervical control and trunk in a risk child diagnosed with BPD.

\section{METHOD}

A female child with a clinical diagnosis of BPD, chronological age of six months and corrected age of two and half months participated in this study.

Data collection was performed at the Joana de Gusmão Children's Hospital from October to November 2014, protocol 805.411/2014.

We conducted a case history with the responsible for the child, which consisted of data on patient identification and previous and current medical history. We conducted a clinical evaluation based on previous and current history of motor performance and postural control.

From the data obtained in the interview, there was extreme prematurity ( 26 weeks gestational age) and low weight ( $965 \mathrm{~g}$ ), the assessed child born of cesarean section. The mother reported having a pregnancy uneventfully until the 24th week of pregnancy, and from that, there was cervical incompetence without possibility of continuing the pregnancy. It were totaled
55 days of mechanical ventilation, 32 days of non-invasive ventilation, 29 days with use of nasal oxygen catheter and 11 days in ambient air; and was subjected to five surgeries.

During hospitalization, she performed physiotherapy daily during the days of the week, with sessions of one hour each.

Through the initial clinical evaluation, it was noted that in the physical examination, the patient had no cervical and trunk support, did not roll over and stood with his head in the midline. She often slept in the supine position, with signs of respiratory distress (subcostal drawing, nose flaring, wishbone retraction and paradoxical breathing), pale, anicteric, nasal oxygen by 1 liter/minute, with global hypomobile and absence of primitive reflexes, with exception of the swallowing reflex.

\section{Intervention}

Based on the initial evaluation, we had as objective of treatment the stimulation of child development generally, aiming the positions not reached until then from training high postures (sitting, standing and squat pivot transfer), in order to improve postural control. Activities were carried out in sitting position, with support in the cervical and trunk; standing position with support on the body therapist and sustaining in the lower limbs; discharge of lateral and anteroposterior weight in the standing position; squat pivot transfer with support in the lower limb. In addition, we passed the family guidance on the periodic exchange position.

\section{RESULTS}

After one month and eight days of intervention (28 consultations), the team that accompanied the child during hospitalization, which was composed of physical therapists and physicians, noted a significant improvement in the overall development.

Through a descriptive analysis, it was possible to verify an increase in active movement and interaction with the environment through smiles and monitoring of the call with the head; reaches the complete cervical extension in the prone position; the roll from supine to prone position; remained stable requiring light support hip in a sitting position. In addition, stay in standing position with cervical and trunk support of the lower limb proximally and was observed positive and negative ground reaction in this position.

Regarding reflections and reactions were observed the presence of Moro, Babinski and palmar reflex, as well as labyrinthine reaction, rectifying reaction and positive and negative reaction to the ground.

\section{DISCUSSION}

Deviations of psychomotor development, ${ }^{(1)}$ may occur due to extreme prematurity and very low birth weight, ${ }^{(15)}$ which are associated with high neurological risk with behavioral disorders, motor skills, posture and motor integration visual. ${ }^{(16)}$ Besides the gestational age and weight, environmental and 
social factors also relate to proper child development. $(17,18)$ Furthermore, the interaction of these factors influence on deviations in psychomotor development. ${ }^{(19)}$

At the beginning of physiotherapy treatment, the patient presented with low active movement and significant NPMD delay, probably because a set of biological and environmental factors. These factors are, prolonged hospital stay, submission to invasive procedures, increased energy expenditure leading to increased respiratory effort, surgical procedures, interaction with the environment damaged due to prolonged stay in the supine position, frequent handling, excessive visual and auditory stimulation, among others.

The usual infant postures can influence the way in which the muscles are recruited and coordinated during postural stability. ${ }^{(10)}$ Proper positioning is a prerequisite for the control and the development of voluntary movements, ${ }^{(20)}$ and the alternation of these, as well as the correct positioning of the infant, can optimize lung function, and stimulate neurosensory and psychomotor development of infants. ${ }^{(21)}$

In the first year of the infant's life, exists a strong relationship between the development of central nervous system and the functions that appear and disappear, causing reflex functions become complex and voluntary ${ }^{(22)}$. The repertoire of motor skills are enriched and include skills such as crawling, walking, running, eye-hand coordination and object manipulation. ${ }^{(10)}$ The sensory system starts functioning even before its complete maturity. In preterm infants occur sensory loss in facilitating and inducing neural maturation and development, ${ }^{(23)}$ and postural adjustments, as a result of low muscle tone and self-organization disability, favor the extension position and hinder the movements in flexion, ${ }^{(23)}$ which favors the engine performance delays. ${ }^{(24)}$ In addition, tactile and vestibular receptors receive little stimulation, while the vision and hearing are superstimulated by disorganized and in excess stimulation of human activity and environmental equipment with damage to the development of premature infants. $(25,26)$

Based on the clinical case presented in this study, the objectives established since the beginning of physiotherapy treatment, were based on the use of postures, which would enable greater interaction between children and the environment around them and, consequently, a positive response to your psychomotor development. The established objectives match with the literature, in which the sensorimotor stimulation programs aim to potentiate this interaction, (27) and are highly beneficial for high-risk infants, ${ }^{(28)}$ because it mitigates or substantially minimizes morbidity, and expand its possibilities the infant development. ${ }^{(28)}$

It consists sensorimotor stimulation by tactilekinesthetic, ${ }^{(20,30)}$ vestibular stimulation, hearing stimulation ${ }^{(31)}$, visual stimulation ${ }^{(32)}$ and positioning. ${ }^{(33)}$ The vestibular stimulation gained emphasis on physiotherapeutic treatment of children evaluated in this study because the stimulation against gravity may favor the gain of postural control. ${ }^{(14)}$ Thus, the stimulation of sitting and standing positions, favored the gain of cervical and trunk control, as when initiated the intervention, the patient remained most of the time in the supine position. From the moment that the family were advised regarding the proposed exercises, along with the periodic exchange of decubitus, more movement was observed in both the supine and in the prone position and greater interaction with the environment.

In the first two months of the infant's life, the acquisition of postural control happens in lying position, ${ }^{(34)}$ being predominant the supine position, and there is a gradual increase in the prone position over time. ${ }^{(35)}$ The cervical control and upper limb support are favored in the prone position, ${ }^{(14,36)}$ once the required cervical stabilization in this position interferes with the organization posture of the whole body. ${ }^{(37)}$ When maintained in this position, motor skills and weight support tend to develop against gravity, not only in this posture, but in others, such as supine, ${ }^{(38)}$ sitting ${ }^{(38-40)}$ and standing(40).

Ensure a normal motor development for age promote better use of brain plasticity ${ }^{(41)}$, thus favoring the development of postural control and the prevention of future changes. Guidance to the family as how to stimulate the children, aiming at a more healthy development, is very important, because from the moment that children can experience their environment with opportunity to explore it, will improve the overall development. Training and guidance for mothers of premature infants demonstrate that these offer greater practical opportunity to their children when compared to infants of mothers without guidance and training. ${ }^{(39)}$

\section{CONCLUSION}

Detect early and intervene as soon as possible in the evolution of risk infants are critical to the overall development of the child. In this report, the high postures allowed greater interaction between children and the environment around them, thus enabling an improvement in motor development by the acquisition of cervical and trunk control. Since this is a case report, these results cannot be generalized. However, there is a need for studies comparing a motor stimulation program with high and low postures in the gain of motor responses for critically ill patients.

\section{AUTHOR'S CONTRIBUTION}

TBM, MM: Design and development (provided the idea for research or article and created the hypothesis); TBM, MM: Methodological design (planning of the methods to generate results); TBM, ADR, CFS: Supervision (responsible for organizing and execution of the project and the manuscript writing); TBM, MM, ADR, CFS: Collection and processing of data (responsible for experiments, patients and data organization); TBM: Analysis / interpretation (responsible for statistical analysis, evaluation and presentation of results); MM, TBM, ADR, CFS: Literature survey (participated in the bibliographical research and articles survey); MM, TBM, ADR, CFS: Wording (responsible for writing a substantive part of the manuscript); MM, TBM, ADR, CFS, GMS, $\mathrm{CJ}$ : Critical revision (responsible for reviewing the intellectual content of the manuscript before final submission). 


\section{COMPETING INTERESTS}

The author(s) declare that they have no competing interests.

\section{AUTHOR DETAILS}

${ }^{2}$ Universidade Federal de São Paulo (UNIFESP), São Paulo (SP), Brazil.

\section{REFERENCES}

1. Formiga CKMR, Pedrazzani ES, Tudella E. Intervenção Precoce com Bebês de Risco. São Paulo: Editora Atheneu, 2010, 199p.

2. Pinheiro RC, Martinez CMS, Fontaine AMGV. Integração viso motora e desenvolvimento global de crianças pré-termo e atermo no início da escolarização. Revist Brasileira de Crescimento e Desenvolvimento Humano. 2014;24(2):181-187.

3. Clark RH, et al. Lung injury in neonates: causes, strategies for prevention and long-term consequences. J Pediatr. 2001;139:478-86.

4. Jobe A. Antenatal factors and the development of bronchopulmonary dysplasia. Semin Neonatal. 2003;8:9-17.

5. Cardoso A S, et al. Estudo exploratório de dor em recém-nascidos prétermos em uma unidade de tratamento intensivo neonatal. Cadernos de Terapia Ocupacional da UFSCAR. 2010;18(2):105-114.

6. Linhares MBM, Carvalho AEV, Bordin MB M, Chimmelo JT, Martinez $\mathrm{FE}$, Jorge SM. Prematuridade e muito baixo peso como fatores de risco ao desenvolvimento da criança. Cadernos de Psicologia e Educação. 2000;10(12):60-69.

7. Baltieri L, et al. Desempenho motor de lactentes frequentadores de berçários em creches públicas. Revista Paulista de Pediatria. 2010;28(3):28389.

8. Eickmann SH, Maciel AMS, Lira PIC, Lima MC. Fatores associados ao desenvolvimento mental e motor de crianças de quatro creches públicas de Recife. Rev Paul Pedriatr. 2009;27(3):282-88.

9. Silva VF, Silva APRS. Desenvolvimento motor do bebê: efeito de um programa sensório-motor em prematuros em unidades de CTI. Fit Perf J. 2003;2(4).

10. Shumway-Cook A, Woollacott MH. Controle motor: teoria e aplicações práticas. 2. ed. Barueri: Manole, 2003.

11. Hwang AW, Chao MY, Liu SW. A randomized controlled trial of routines-based early intervention for children with or at risk for developmental delay. Res Dev Disabil 2013;34:3112-23.

12. Spittle A, Orton J, Anderson P, Boyd R, Doyle LW. Early developmental intervention programmes post-hospital discharge to prevent motor and cognitive impairments in preterm infants. Cochrane Database Syst Rev. 2012;12.

13. Ma L, Yango B, Meng L, Wang B, Zheng C, Cao A. Effect of early intervention on premature infants' general movements. Brain \& Development. 2015;37:387-393.

14. Heck APF, et al. Effect of the inclination of support in cervical and upper limb developmente. Fisioterapia em Movimento. 2014;27(4):601-609.

15. Silva MZ. A alta hospitalar do bebê de muito baixo peso e o cuidado no domićlio. 2012. 114 f. Dissertação (Mestrado) - Curso de Mestrado Profissional em Saúde da Criança e do Adolescente, Universidade Estadual do Ceará, Fortaleza, 2012.

16. Foulder-Hughes L, Cooke RW. Motor, cognitive, and behavioural disorders in children born very preterm. Dev Med Child Neurol, Liverpool. 2003;45(2):97-103.

17. Mancini MC. Inventário de avaliação pediátrica de incapacidade (PEDI): manual da versão brasileira adaptada. Belo Horizonte: UFMG, 2004.

18. Silveira RC, Procianoy RS. Lesões isquêmicas cerebrais no recém nascido pré-termo de muito baixo peso. Jornal de Pediatria. 2005;81(11):23-32.

19. Rodrigues LP, Saraiva L, Gabbard C. Development and structural validation of an inventory for assessing affordances in the home environment for motor development. Res Exerc Sport, 2005.
20. Barrabas J, Fonseca A, Guimarães CLN, Lima GMS. Relationship between positioning of premature infants in Kangaroo Mother Care and early neuromotor development. Jornal de Pediatria. 2006;82(6):475-80.

21. Madlinger-Lewis L, Reynolds L, Zarem C, Crapnell T, Inder T, Pineda R. The effects of alternative positioning on preterm infants in the neonatal intensive care unit: A randomized clinical Trial. Research in Developmental Disabilities. 2014;35:490-497.

22. Telles MS, Macedo CS. Relação entre desenvolvimento motor corporal e aquisição de habilidades orais. Pró-Fono. Revista de Atualização Científica. 2008;20(2):117-122.

23. Vanderveen JA, Bassler D, Robertson CM, Kirpalani H. Early interventions involving parents to improve neurodevelopmental outcomes of premature infants: a meta-analysis. J Perinatol 2009;29:343-51.

24. Adamson-Macedo E, Arttree J. (1994). TAC-TIC therapy: The importance of systematic stroking. British Journal of Mildwifery. 1994;2(6):264-269.

25. Bonnier $C$. Evalution of early stimulation programs for enhancing brain development. Acta paedicatrica. 2008;97(7):853-8.

26. Arpino C, Compagnone E, Montanaro ML, Cacciatore D, De Luca A, Cerulli A, Di Girolamo S, Curatolo P. Preterm birth and neurodevelopmental outcome: a review. Childs Nerv. Syst. 2010;26:1139-1149.

27. Pêgo JA, Maia SM. A importância do ambiente nodesenvolvimento do recém-nascido pré-termo. DisturbComun. 2007;19(1):39-50.

28. Gama D, Ferracioli F, Corrêa SMP. Stimulation motosensorial in babies in risk in hospitals. Reabilitar. 2004;6(23):45-50.

29. Vickers A, Ohlsson A, Lacy J, Horsley A. Massage for promoting growth and development of preterm and/or low birth-weight infants. The Cochrane Database ofSystematic Reviews. 2004;2:1-42.

30. Ferreira AM, Bergamasco NHP. Análise comportamental de recém-nascidos pré-termos incluídos em um programa de estimulação tátil-cinestésica durante a internação hospitalar. Rev. Bras. Fisioter. 2010;14(2):141-148.

31. Field DJ, Dorling JS, Manktelow BN, Draper ES. Survival of extremely premature babies in a geographically defined population: Prospective cohort study of 1994-9 compared with 2000-5. British Medical Journal. 2008;336(7655):1221-1223.

32. Graziano RM, Leone CR. Problemas oftalmológicos mais frequentes e desenvolvimento visual do pré-termo extremo. Jornal de Pediatria. 2005;81:1.

33. Sweeney JK, Gutierrez T. Musculoskeletal implications of preterm infant positioning in the NICU. Journal of Perinatal \& Neonatal Nursing. 2002;16(1):58-70.

34. Rocha NACF, Silva FPS, Toledo AM, Tudella E. Variability in the levels of postural control in 0-4-month-old infants. Infant Behavior \& Development. 2009;32:376-380.

35. Carmeli E, Marmur R, Cohen A, Tirosh E. Preferred sleep position and gross motor achievement in early infancy. European Journal Pediatrics. 2008;168(7):11-15.

36. Rattliff-Schaub K, et al. Relationship Between Infant Sleep Position and Motor Development in Preterm Infants. Journal of Developmental \& Behavioral Pediatrics. 2001;22(5):293-299.

37. Campos D, Santos DCC. Controle postural e motricidade apendicular nos primeiros anos de vida. Fisioterapia em Movimento. 2005;18(3):71-77.

38. Dudek-Shiber L, Zelazny $\mathrm{S}$. The effects of prone positioning on the quality and acquisition of developmental milestones in four-month-old infants. Pediatric Physical Therapy. 2007;19:48-55.

39. Formiga CKMR, Pedrazzani ES, Tudella E. Desenvolvimento motor de lactentes pré-termo participantes de um programa de intervenção fisioterapêutica precoce. Revista Brasileira de Fisioterapia. 2004;8(3):23945.

40. Lima CD, Carvalho RP, Barros RM, Tudella E. Dois métodos diferentes para análise cinemática dos movimentos de cabeça durante a coordenação visocefálica de lactentes. Revista Brasileira de Fisioterapia. 2008;12(5):425-31.

41. Resegue R, Puccini RF, Silva EMK. Risk factors associated with developmental abnormalities among high-risk children attended at a multidisciplinary clinic. São Paulo Jornal de Medicina. 2008;126(1):4-10. 